Delia BALABAN*

Maria MUSTĂȚEA**

\title{
Users' Perspective on the Credibility of Social Media Influencers in Romania and Germany
}

\begin{abstract}
The present research addresses the issue of source credibility of social media influencers from the perspective of users. Social media influencers are defined as online personalities with a large number of followers, across one or several social media platforms. They have a complex role, being content creators, online opinion leaders, and even entrepreneurs. Influencer marketing is becoming a more and more relevant component of current advertising campaigns worldwide. A consistent body of literature has underlined the importance of source credibility for the effectiveness of advertising. Recent researches on Source Credibility Theory (Teng et al, 2014; Djafarova \& Rushworth, 2016; Munnukka et al 2016; Lou \&Yuan, 2018) have stressed the influence of trustworthiness, expertise, similarity and attractiveness as elements of source credibility on perceived trust in influencer marketing. In order to gain better insights, we chose to conduct qualitative research that can allow us an in-depth perspective on the phenomenon of source credibility in influencer marketing. We carried out four group discussions in Germany and five in Romania. We explored the differences and similarities regarding the users' perception of the perceived credibility of social media influencers.
\end{abstract}

Keywords: source credibility, social media influencer, influencer marketing, advertising research.

\section{Introduction}

Social media is a dynamic field where platforms and usage practices are subject to constant changes in an established culture of connectivity with multi-directional information flow (Van Dijck, 2013, Van Dijck et al, 2018). Social media is defined as computer-mediated communication, where individuals generate the content of their own, see and interact with the content of their friends' or other users online (Carr and Hayes, 2015). The use of social media platforms has become a relevant element in the media diet of the majority of the population worldwide. Especially younger adults use mobile platforms much more frequently than all others. This has been proved to influence consumer trust. Advertising is influenced by the in-

* Babes-Bolyai University, Cluj-Napoca (Romania), balaban@fspac.ro.

** Babes-Bolyai University, Cluj-Napoca (Romania), mustatea@fspac.ro. 
teraction with the platforms and new instruments emerged (Stewart \& Cunningham, 2017; Gottfried \& Shearer, 2016). In 2018 the number of social media users grew by $13 \%$ to 3.2 billion accounts worldwide (Chaffey, 2018) building a collective system of virtual spaces where consumers are connected within and across multiple interactive platforms that build a social media ecosystem (Ham et al, 2018, p.3).

According to the communication-persuasion model (McGuire, 2001), there are five components of persuasive communication that determine the effectiveness of advertising: the source, the message, the channel, the receiver, and the destination. The present research addresses the issue of perceived source credibility. The focus is on social media influencers and on influencer marketing as an advertising instrument that is gaining more popularity among users and marketers (Carpenter, Childers, et al, 2018). The Romanian users' perspective and the perspective of users coming from Germany, a Western European country where social media influencers have a relatively long history, were analyzed. There are relevant differences between the German and the Romanian traditional and online advertising markets in terms of the size and the active brands. Influencer marketing campaigns have a longer history in Germany than in Romania. There are differences between Romanian and German popular social media influencers when it comes to the number of followers, international reach and relevance. Even if both countries are members of the European Union, there are differences in terms of legislation and market regulations regarding advertising and influencer marketing. Nevertheless, there are also similarities: both Romanian and German young people prefer using the Internet and social media to traditional media.

Data collected in Germany with respect to the use of the Internet versus the use of traditional media revealed significant differences between the audience aged 14-29 and other target audiences. The Internet is the favorite media for the former. Their daily linear television use dropped from 200 minutes in 2005 to 150 minutes in 2015. Meanwhile for audiences aged 50 or older, there was an increase use of linear television from 180 minutes daily in 2005 to 300 minutes daily in 2015. Even for the segments under 14 and between 30 and 49, an increase of linear TV use between 2005 and 2015 was reported. Also, traditional radio use and the use of newspapers for early stage adults (14-29) dropped in the above mentioned time frame (bpd, 2016).

Even if television is still the leading media in Romania in terms of audiences, Internet penetration in Romania registered a growth from 70\% in 2016 to $73 \%$ in 2017 . The group of young users aged 16-24 were the most active, followed by 25 to 34-year-olds (MFB, 2018). Thus we assume that one of the most efficient ways to target this group with advertising messages is via the Internet and particularly via this new instrument called influencer marketing.

Blogs, Vlogs, Instagram and YouTube accounts are the favorite channels for social media influencers and thus for influencer marketing. Some of the social media influencers used to run blogs, personal web pages that allow interaction. In the last years, more and more influencers have moved to vlogging activities by posting social videos especially on YouTube (Nirschl \& Steinberg, 2018). Instagram was the fastest growing social media network both in Germany and Romania in 2018. Germany is even in the top ten countries worldwide when it comes to the number of active accounts on the above-mentioned platform. The entire young population of Germany (aged 14-19) is reported to be active on social networks. Active social media penetration in both countries is relatively similar: Romania (51\%) and Germany (46\%). Data from October 2018 revealed that only 38.6\% of Germans use Facebook and 
$23.8 \%$ use Instagram. In the case of Romanians, 50.6\% use Facebook and 18.7\% use Instagram (Statista, 2019a; 2019b; 2019c).

\section{Social Media Influencers and Influencer Marketing}

Social influence describes the phenomenon of changing opinions and actions due to the interactions with the people around us. Under the umbrella term of 'social influence', scholars understand a wide range of concepts such as socialization, obedience, compliance, and persuasion (Kelman, 1958; Cialdini, 2001). The complex contemporary media environment has specific features that are linked to social influence (Flanagin, 2017). Social media influencers are part of this environment. They are online personalities with a large number of followers, across one or several social media platforms such as YouTube, Instagram, Snapchat, or personal blogs. They have influence over their followers (Freberg et al., 2011; Lou \&Yuan, 2018; Versamis, 2018; Nirschl \& Steinberg, 2018). Their influence consists in the fact that their ideas and their behaviors will not only be positively evaluated by their followers, but also imitated. The products that they present online will be sold. However, a larger number of followers does not necessarily mean more influence. Besides the issue of false followers that can be purchased online, more and more marketers prefer to work with so-called microinfluencers, who have thousands of followers instead of tens of thousands, but a higher engagement (Nirschl \& Steinberg, 2018).

Influencers can be seen as online opinion leaders in the sense of the definition of opinion leader within the framework of the two-step communication flow theory (Katz \& Lazarsfeld, 1955). Influencers have a strong relationship with their communities, in this case with their followers. Micro-influencers especially have a strong interaction with their group. This interaction is quantified in the number of likes, comments, and direct messages. Similar to the traditional opinion leaders, influencers seem to know what is new in their fields of interest. They are usually cosmopolite personalities and, similar to the opinion leaders, their influence takes place horizontally. Liu (2007) developed the theory of multistep flows of communication related to online opinion leaders in the context of digital platforms with direct feedback possibilities. Audiences often perceive influencers as their peers.

A relevant aspect related to social media influencers and audiences is para-social interaction (PSI), defined as the illusion of a face-to-face relationship with a media performer (Horton \& Wohl, 1956). PSI develops and strengthens with each encounter with media performers. In the case of social media influencers who usually disclose aspects of their lives on a daily basis, a strong PSI will be developed in a short time (Coliander \& Erlandsson, 2015). Previous research has emphasized the importance of advertising disclosure for transparency and for a healthy relationship between social media influencers and their communities. Unfortunately, advertising disclosure on Instagram is still not compulsory in some countries such as Romania.

Some researchers stressed that target audiences perceive social media influencers as more accessible, believable, intimate, credible and influential in the purchase behaviors than traditional celebrities (Djafarova \&Rushworth, 2017). Social media influencers are easy to relate to, as they share aspects of their everyday life. They create the illusion of a face-to-face relation, generating para-social interactions. Thus, advertising messages can be perceived as the influencers' unbiased opinion and have a stronger persuasive power (Abidin, 2015; 2016; DeVeirman, 2017). Social media influencers have been described as "micro"-endorsers, com- 
pared to "bigger" celebrity endorsers (Hall, 2015). Traditional celebrities can become social media influencers if they are active on platforms, have a significant number of followers, and become regular content-creators (Lou \& Yuan, 2018). Social media influencers are consumers as well, consumers that communicate information about products on social media. Influencer marketing is a form of native advertising, a variety of techniques by which advertising messages are crafted to be integrated into non-advertising content (Wojdynski, 2016). Native advertisements on Instagram both in the form of posts and stories use images that resemble the activity of real peers. This practice maximizes message effectiveness and minimizes audience resistance. Usually, social media influencers present products in a friendly way, as if they were testing the products and making recommendations to peers. It is like the title of a recent article suggests: Is That My Friend or an Advert? The Effectiveness of Instagram Native Advertisements Posing as Social Posts (Johnson et al, 2019). The tone-of-voice is natural and friendly. Influencer marketing is a form of electronic Word of Mouth Marketing in the sense that product recommendations are posted online (Erkan \&Evans, 2016).

Social media influencers perform complex activities, being content creators and, therefore, advertising creators, opinion leaders and entrepreneurs (Carpenter, Childers, et al, 2018). They "can range from being celebrities to more micro-targeted professional or non-professional 'peers"' (IAB, 2018). Within the literature on this topic based on the range of followers, various influencer types were defined: peer-to-peer level or micro-level influencers (500-10,000 followers), macro influencers (up to 1 million followers), influencer celebrities with 1 million-plus followers (Gottbrecht, 2016). There is a link between the number of followers and the opinion leadership (Hwang, 2015; De Veirman, 2017).

Brands continue to use less or even abandon traditional media ads and move to more effective instruments with higher authenticity and credibility such as influencer marketing (deVries et al, 2012; De Veirman et al, 2017). This was defined as a marketing strategy having marketers and brands invest in selected social media influencers that create branded content and disseminate it on their channels with the goal of increasing brand awareness and/or their purchasing decisions (Lou \& Yoan, 2018). The popularity of this instrument has grown exponentially in the last years due to its ability to reach a significant number of consumers in a short period of time because it generates engagement with target audiences and is not as expensive as traditional advertising campaigns (Phua et al, 2017; Evans et al, 2017). This new marketing tool has some similarities with other forms of native advertising because its appearance looks like editorial content. Influencer marketing looks similar to its surrounding media content (Lee et al, 2016; Matteo \&Dal Zotto, 2015).

Besides the growing use of social media, there are other factors such as the increasing trust in personal recommendations instead of ads when it comes to purchasing products, which speaks for influencer marketing as a relevant advertising tool. Research has emphasized the link between platform usage and greater trust in advertising on that particular platform (Stewart \& Cunningham, 2017). Even if the young generation prefers online media, using old strategies on new channels is not an option. Millennials (born between 1981 and1995) and generation Z (born between 1996 and 2012) are familiar with the use of ad blockers in order to avoid ads. A unique feature of influencer marketing is that it encourages consumers to communicate with one another about brands on social media. Consumers' expressions are much more evaluated than advertising impressions on markets where traditional advertising methods no longer obtain significant results (Kelley and Fay, 2012; Long, 2016; Carpenter Childers et al., 2018). 
Influencer marketing is a relatively new advertising instrument thus the body of literature on this subject is relatively new. It works "best when the content is natural, genuine, and realistic coming from the social media influencers" (Carpenter, Childers et al., 2018, p. 12). Successful influencer marketing is a delicate balance between the influencer's authentic voice and brand advertising strategies. Previous findings underlined that in an increasingly cluttered media environment too much advertising can damage the reputation of bloggers: the source of their persuasion can become the source of their undoing (Colliander \& Erlandson, 2015, p.120). This is why, similar to bloggers, social media influencers are advised to properly disclose sponsored posts and advertising. A very interesting research topic is to determine the circumstances that determine a follower to unfollow an influencer because of too much advertising.

\section{Source Credibility Theory}

Media credibility is a concept in the communication sciences that has not lost relevance for the communication research over the last decades because of constant changes in the media environment (Metzger et al., 2003, 2010, Lazer, 2018). At the practical level media credibility has significant consequences for the users (Metzger et al, 2003, P.294) and online media credibility is related by some authors to the spreading of inaccurate and biased information available online, of fake or false news or dysfunctional information (Chadwick et al., 2018).

Long before social media emerged, the concept of media credibility was analyzed taking into consideration its three levels: the credibility of the source, of the message and of the channel that carries it. Previous research described the credibility of sources using several elements: trustworthiness and expertise on the one hand (Wilson and Sherrell, 1993) and dynamism, composure, and sociability on the other hand (Gass and Seiter, 1999, Perloff 1993). Organizations can serve as sources and corporate credibility is defined as the degree to which consumers, investors, and others believe in the organization's trustworthiness and expertise (Goldsmith et al, 2000). With respect to the Internet, research has been conducted on the credibility of web sites (Fogg et al, 2001, Shon, et al., 2000, Flanagin et al, 2001). Previous research on the credibility of web sites (Johnson and Kaye 1998, 2000; Mashek, 1997, Kim et al., 2001, Kiousis, 2001, Sundar and Nass, 2001) revealed that credibility plays a role in the search for information, people being more likely to select a source that they judge as credible (Kerstetter \& Cho, 2004). Appearance and graphical design issues, disclosure and security measures, functionality and connectedness and accuracy and comprehensiveness of content are only some of the new key elements of social media credibility (Metzger et al., 2003, 2015).

Source credibility refers to the consumers' perception of the source of information. Defining the concept of source credibility on social media can be a challenge because of the presence of anonymous and multiple authors; there are no gatekeepers, we are faced with the convergence of genres and advertising blending. People tend to believe certain sources if others do so as well (Metzger et al, 2010). Social media influencers are considered to be both sources and media.

Previous research on source credibility emphasized the role of the trustworthiness, attractiveness, and expertise of the communicator in the particular case of celebrity endorsement ads (Ohanian, 1990, Teng et al, 2014, Djafarova \& Rushworth, 2016). Within the theoretical framework of the Source Credibility Theory, based on three aspects: trustworthiness, expertise, and attractiveness, Munnukka et al (2016) added a new element, applied exclusively in 
the case of social media influencers, which is similarity (the likeness between influencers and their followers, concerning demographic or ideological factors). In line with the Advertising Value Model, Lou \& Yuan (2018) have developed the Factors in Social Media influencer Value Model (SMIV). This model explains the role of source credibility on consumer behavior and redefines the trust concept in the influencer context. According to this, credibility influences the perceived trust, brand awareness and also the purchase intention. More specific, three of the credibility elements: trustworthiness, similarity, and attractiveness proved to have positive effects on perceived trust, brand awareness, and purchase intention. Besides credibility, advertising content value, in this case, influencer-generated content, consisting of informative and entertainment values can have positive effects on perceived trust, brand awareness, and purchase intentions as well. Argument quality has been proved to be a significant predictor of perceived information credibility (Metzger et al, 2003; Xiao et al, 2018).

\section{Methodology}

Our main research objective was to analyze social media influencers' perceived credibility and its effects on how influencer marketing works. We explored the credibility concept and its implications on perceived trust in influencer marketing. The aim of the present research is to contribute to the Source Credibility Theory applied to the particular case of social media influencers.

We focused on the following research questions:

RQ1: How do users define social media influencers and what are the elements that influence their credibility?

RQ2: What does influencer marketing represent for users and what are the mechanisms that make this instrument effective for users?

People tend to follow similar activities as their peers because social influence plays a critical role in deciding to follow social media influencers and getting to know influencer marketing. Adopting innovation is a process that needs time. Social media influencers and influencer marketing emerged on the Romanian advertising market later than on the German one. In our research, we would like to explore the possible implications for this later adoption of influencer marketing in Romania regarding how the trustworthiness of the bloggers is perceived. There are other relevant differences between the Romanian and the German market sizes. In terms of the number of followers, the international relevance of German influencers is higher than the relevance of their Romanian colleagues. International brands have higher advertising expenditures on the German market than on the Romanian one. These are some of the reasons why we decided to explore the differences and similarities related to our research subject between Romanian and German users.

RQ3: What are the differences in the perception of social media credibility of influencers for Romanian and German respondents?

In order to gain insight into the perceived credibility of social media influencers, we chose to conduct qualitative research in the form of focus groups that can allow us an in-depth perspective on the phenomenon (Tuchman, 2002, p. 80). In-depth research can provide methodological tools in order to explain the meaning of influencers' credibility and its implication 
on how influencer marketing works. (Djafarova \& Rushworth, 2016). A qualitative approach provides the opportunity to explore the participants' construction of the meaning of the influencers' credibility based on their daily online experience and it is an accepted method in advertising research (Halley et al, 2014; Carpenter Childers et al, 2018). As Wimmer \& Dominick (2011) suggest, the rationale behind the focus-group choice derives from our desire to enhance our understanding about this subject, as well as to discover a wide range of opinions coming from the interviewees (p. 132).

Non-probability purposing sampling was used. We carried out four group discussions in Germany and five groups discussion in Romania in the time frame September-December 2018. The respondents were between 10-12 in each focus group and the ages ranged from 19 to 21 for the Romanians and from 20 to 24 for the German respondents. They were all gender-mixed focus groups. The participants were students enrolled in various bachelor programs in Romania (Babe?-Bolyai University, Cluj-Napoca) and Germany (Hochschule Mittweida). The main condition for the voluntary participation in these focus groups was to be a YouTube and/or Instagram user and to follow or have followed social media influencers on one of these platforms.

Data analysis was performed based on categories related to the themes (Creswell, 2009; Tuchman, 2002). The main themes that we addressed during group discussions were: what is a social media influencer, how influencer marketing works, what are the differences between influencer marketing and advertising. We linked these aspects to the theoretical model of the factors in the social media influencer value, and to the perceived credibility sources: expertise, trustworthiness, attractiveness, and similarity, as well as the informative and entertainment values of the influencer-generated content (Lou \& Yuan, 2018).

\section{Findings and discussion}

\section{Theme 1: Social Media Influencers}

The first subject of the focus group addressed the way the participants define social media influencers. The respondents were familiar with the elements of social media influencer definitions that were described in the theoretical part of this research: "an influencer will always be found on social media. This is his or her environment" (male, 20). Young people follow influencers on several platforms. They pointed out that, for them, influencers are role models, sources of inspiration, unique personalities. There is a strong desire among followers to be like them.

An influencer "is a personality who guides your personal values; he or she helps you develop your own system of values, should you not have one already established" (male, 20, Romania). An influencer "is a person who manages to influence other people through his or her opinions" (female, 20, Romania) and "an opinion leader for the group the brand targets" (male, 21, Romania). Respondents are familiar with the advertising activities of influencers, some of them even consider that the influencers' role is mainly connected to the marketing strategies and should be taken as such. An influencer is "a person who is constantly followed for information that helps you make the decision to buy certain products" (female, 21, Germany); "As harsh as it may sound, an influencer is a marketing instrument used for selling products in a more personalized manner" (male, 20, Romania). 
Not everybody can become an influencer. Financial support prior to launching into such a business is necessary. In order to become a successful influencer ", you must have a considerable amount of money" (female, 20, Germany). There were also some negative opinions regarding influencers: "it's all about making money. Sometimes it is difficult to see the authenticity anymore" (female, 22, Germany); "You don't know if you can trust them anymore or if what they disseminate online is only advertising" (female, 22, Germany); "All young people do is copy them and this can be a problem"(male, 23, Germany); "they make too much money" (female, 20, Romania). Being an influencer is not an easy job, there is a social pressure to look perfect, to show the perfect life and the perfect lifestyle: "being an influencer is a challenge. There is a strong competition between influencers for the perfect feed. There is a lot of pressure to be better than others" (male, 23, Germany).

\section{Theme 2: Influencer Marketing}

Participants were asked to describe how advertising works with the help of social media influencers and to pinpoint the differences from traditional advertising. In fact, the second subject of the focus group addressed the way the participants define influencer marketing. They suggested a number of key elements that are compulsory for influencer marketing: "you need someone who actively promotes oneself online" (male, 20, Romania) and "you need a target group to follow you and engage with you, so you can promote or launch products which they will buy" (female, 20, Romania). Some participants recognized the marketing mechanisms: "It is a new marketing strategy" (female, 19, Germany) and "it is a new, modern form of making online recommendations" (male, 20, Romania).

Specific traits of the process were pointed out. Thus, influencer marketing "exploits niches" (female, 20, Germany) and "it is a service which informs people about a product, through a person who has a pool of followers" (female, 20, Romania). Furthermore, the importance of the group's specificity and similarities between it and the influencer was noted: "the way an influencer will promote a product is based on the culture of the group of followers and what they have in common" (female, 21, Germany).

Influencer marketing ensures engagement and real-time reactions: "there is a direct interaction with the followers. They really like this" (female, 19, Romania); "It makes brands known among the influencer's followers." (male, 20, Romania). Influencer marketing works when there is a relationship between the influencers and their audiences: "influencer marketing strategies are more effective for younger target groups. They are much more relevant than traditional advertising" (female, 20, Germany) and "the pool of consumers is always welldefined. You know what kind of people follow the influencer" (female, 21, Romania).

Differences between influencer marketing and traditional ads were underlined in terms of targeting audiences and also in terms of costs: "In traditional advertising, you pay the agency, the media, etc. Influencer marketing means you only pay the influencer. From there on, he or she is in charge of creating the content" (female, 20, Germany); "and the influencer makes use of his or her channels. And his or her specific group of followers" (female, 21, Germany). Influencer marketing is not always perceived as a form of advertising: "the promotion of a product through an influencer gives the sensation of "unofficial", you know? You are not always aware of it being a marketing scheme." (male, 19; Romania); "Ifeel much closer to an influencer than to a celebrity in a regular ad" (female, 23, Germany). Influencer marketing is perceived as something between a model of peer endorsement and a model of celebrity endorsement. 
Differences and similarities between Instagram and YouTube, the two main platforms for influencer marketing were pointed out during the group discussions. The main differences are in the length of the materials posted and the type of reactions: "Instagram is more accessible than YouTube. On YouTube, you have to edit and upload a larger material." (female, 20, Romania); "On Instagram, on the other hand, you can post something quickly and have real-time reactions" (female, 19, Romania). Instagram encourages engagement with the audience: "Instagram is more interactive. You can have a lot of initiatives" (female, 21, Romania). "On Instagram, you have to be good at creating interesting content. The time for promoting anything is extremely short" (male, 22, Romania) and "You must be quick and efficient. On YouTube, you have people who can afford to edit larger video materials" (female, 20, Germany). However, there were voices who claimed one completes the other: "I believe Instagram is like a hook. It shows you something appealing than it sends you to YouTube for more details" (male, 21, Romania); "The impact on Instagram is much more rapid. But, personally, I go from there to YouTube, as it offers more details about what I am searching" (female, 20, Germany). This statement was also supported by an idea launched in another focus group: "On Instagram, you have the short version of the materials presented on YouTube" (female, 19, Romania). This is why social media influencers prefer to use both platforms.

Engagement is different on Instagram versus YouTube: "the two differ in the relationship between the public and the content. On Instagram, you wait to see reactions in a day or two at most. On YouTube, you may have a consistent number only after a month or two" (male, 20, Romania). The accessibility to the two platforms is different as well: "Instagram is much more accessible. You can access it several times a day. With YouTube, things are different" (female, 20, Romania). Thus, it is suggested that the immediate reactions received on Instagram are more compelling than the views or reactions on YouTube, as a long-time wait is less desirable. The solution for efficient influencer marketing is to use both platforms and their specific advantages.

\section{Theme 3: Source Credibility}

Credibility is an important asset for influencers: "first of all, an influencer must be credible" (female, 20, Romania). According to the respondents, influencers have a relevant amount of expertise in their field, and influencer marketing benefits of more trustworthiness than other advertising strategies. Source credibility influences purchase intention: "If we see a product which is promoted by an influencer that we follow and like, the probability of buying it increases" (male, 20, Romania). Influencer marketing is a "more credible tactic than traditional ads" (male, 21, Germany). When it comes to the products the influencers are promoting online there must be compatibility between the products and the influencers. Choosing to promote products of lower quality than advertised can damage both influencer and product credibility. Trustworthiness is important: "in order to be an influencer, one must have the trust of many others and know what one is talking about" (male, 19, Germany). An influencer "promotes products and ideas, but it is important to be a good match with the product" (female, 20, Romania). Promoting products that are far too expensive for the core audience can also damage credibility.

Key elements that make influencer marketing work are the similarities between influencers and followers: "Influencers are like us", "you feel you have a direct connection to the influencer" (male, 19, Romania); "Even if many seem to have luxurious lifestyles, they lead 
normal lives" (male, 20, Romania). Following the influencers from the beginning of their online career seems to enforce the bond between them and the followers: "I have followed influencer X since she was an ordinary girl, just like me. I still follow her now when she promotes brands that I cannot afford to buy" (female, 22, Germany). If influencers advertise too much for brands far too expensive for their target audiences, the bond between them and the followers can be damaged. Our data confirm the results of previous research. The respondents repeatedly suggested that influencers have unique approaches through which they build trust and brand credibility (Carpenter Childers et al., 2018).

Similarity is a relevant aspect of source credibility that can contribute to purchase intention: "I feel closer to an influencer when I buy the products he or she advertised." (female, 22 , Germany). Influencers are perceived as friends who deliver insights into their daily lives via storytelling on social media platforms. For the public, influencers are people with a high degree of identification with their target audiences. An incentive to follow influencers "lies in the possibility to watch them almost live every day" (female, 22, Germany).

Several respondents (both men and women) underlined the fact that in order to be a social media influencer it is important to be attractive: "influencers are individuals with the ability to charm and entertain a large number of people and to persuade them" (male, 20, Romania). Besides attractiveness, expertise contributes to the perceived credibility of influencers: "it is a promotion technique through which people make use of their know-how and appeal to the public." (male, 21, Romania).

The influencers' expertise is perceived as gender-related: "Men are more active when it comes to gadgets and cars" (female, 20, Romania); "We have more women who are beauty and lifestyle influencers" (female, 19); "The beauty zone is mainly covered by women. Although, recently, I have seen men talking about beauty, as well. And it is more exciting because it is a new element" (female, 20, Romania); "Photography influencers are quite balanced, in my opinion. Both women and men can be found here." (male, 19, Romania). What about IT? "In IT we used to have mostly men, but now I have noticed there is a big trend to also include women and promote the fact they can do an equally good job." (male, 20, Romania). Several professional fields are perceived as being strongly related to the development of social media and influencer marketing. Among them, the respondents mentioned not only the traditional social-mediated areas of fashion, beauty, and travel but also fitness, architecture, and design. Expertise is particularly evaluated in these fields.

The analysis of data collected during the focus groups revealed a connection between expertise and trustworthiness as important elements of source credibility, as pointed out by previous research (De Vierman et al., 2017).

\section{Theme 4: Advertising value}

The respondents considered that they relied much more on information received from influencers than from traditional advertising messages. Often, influencers offer video "proof" by putting products to the test. Thus, influencers present information about relevant products for the target audiences: "Information about fashion trends, restaurants, and interesting locations can be useful for followers" (female, 23, Germany). The followers' trust in the influencers' messages comes from a high degree of the enjoyability of the created content. The entertainment value of influencer marketing makes this instrument more "likable" than traditional ads: "It is a strategy through which people do not feel annoyed, even if something is 
sold right under their noses" (female, 20, Romania). As some respondents suggested, the influencers they follow promote products and lifestyles that are accessible to their followers. A major preoccupation of influencers is to entertain their followers with the help of storytelling. By doing this, the likelihood of raising promoted brand awareness increases. Respondents stressed the need for a balance between paid content and non-advertising content. Too much influencer marketing can have negative effects on their perceived credibility. Users should enjoy the content.

\section{The Comparative Perspective}

Data provided by the group discussions conducted in Romania and Germany showed no major differences regarding the understanding of the concept of social media influencers. Both Romanian and German respondents were familiar with influencers and influencer marketing even if the Romanian advertising market introduced them with a certain delay compared to the German one. The tone of some of the discussions carried out in Germany was much more critical of the materialistic values promoted by the influencers' lifestyle. German students also addressed issues such as sustainability, equity, which should be promoted by influencers to a greater extent.

The importance of source credibility for influencer marketing was underlined during focus groups both in Romania and in Germany. Trustworthiness is often related to the choice of the products the influencers advertise. Even if social media influencers should be similar to their audience groups, they must also have something special. Being a social media influencer is a job and also a goal, as some of our respondents told us. It is a goal because young people perceive only the positive side of this profession, which is what gets posted online. They see influencers traveling, staying in the best hotels, going to the best restaurants and getting all kinds of products for free. Attractiveness plays a crucial role in becoming a successful influencer. The relevance of expertise is related to the field. The perspective of the users is that some fields like high fashion, luxury brands are more strongly advertised on social media in Germany than in Romania. Other often-mentioned examples of fields where expertise is important are sport and fitness. The category of sport and fitness is a relevant branch for influencer marketing in Germany. During our group discussions, fitness influencers from Germany and their activity were often mentioned. Several respondents even underlined the idea that they felt inspired by sports influencers in their daily life. Being a professional in this field nowadays is almost impossible without social media, emphasized one of the respondents. This is the user perspective. A comparative content analysis of the relevant fields of influencer marketing between the two countries is an interesting direction for future research.

\section{Conclusions}

In line with the results of previous research, the main conclusion of the present study is that attractiveness, trustworthiness, expertise, and similarity are perceived as important elements of the perceived credibility of social media influencers (Munnukka et al 2016; Lou $\&$ Yuan, 2018). Social media influencers have engaged audiences both in Romania and Ger- 
many. Our respondents were familiar with social media influencers and influencer marketing. Critical aspects that can influence source credibility in influencer marketing were also underlined. Striking a balance between advertising and non-advertising content, advertising for high-quality and suitable products for the followers can contribute to the influencers' trustworthiness. Previous research pointed out that too much advertising on social media can have a negative impact on para-social interaction and on the trustworthiness of the influencer (Coliander \& Erlandsson, 2015). Similarities with celebrity endorsement were pointed out. In traditional advertising, celebrities were also advised not to promote too many products. Besides the restriction in promoting products from brands of competitors, both celebrities and influencers have to advertise products that are compatible with their image. Each time a celebrity or an influencer promotes a product, a transfer of image takes place. This transfer is bidirectional: not only is the image of the promoter transferred to the product, but also the other way around.

Attractiveness is as an important feature of social media influencers. Not everybody can become an influencer, even if they appear to be "one of us" in the eyes of the users. Influencer marketing is, first and foremost, a model of peer endorsement, which is one o the main difference between celebrity endorsement and influencer marketing when it comes to trustworthiness. Peer endorsement also adds elements of Word-of-Mouth Marketing to influencer marketing. It has the potential to reduce negative attitudes towards advertising activities performed by an influencer.

The aim of the present research was to address the issue of source credibility of social media influencers from the users' perspective in two different countries. According to our data, the users' perspectives in the two countries are similar. The adoption of Instagram as a new social media tool took place with no significant delay between Romania and Germany. The fields of interest can be different, based on the individual predisposition and not necessarily based on cultural aspects. The users' tone was a bit critical towards influencer marketing during the group discussions that we conducted in Germany. Qualitative research allowed us to ask in-depth questions in order to collect data on the users' perception. This study has an exploratory nature and thus we are aware of its limits: the results cannot be generalized. The theoretical sample of students is also a limit of the research. Students are heavy users of social media and their answers might be different from the answers of the nonstudent population (Evans et al, 2017).

Influencer marketing is a fast growing area that is yet to evolve (Lou \&Yuan, 2018). The present paper contributes to the academic research on influencer marketing in Romania and Germany and it provides a further understanding of this phenomenon. Its results can be used for developing future cross-cultural analysis. There are also practical implications of this study: marketers should consider using influencer marketing as a tool for their campaigns, taking into consideration the importance of finding a match between the products to be advertised and the profile of the influencers. Our findings can also be relevant to influencers, who should be aware of the importance of trustworthiness for building a healthy and longlasting relationship with their communities and also with the brands they are promoting. The peer endorsement dimension should be cultivated and the attractiveness of using both Instagram and YouTube as complementary platforms should be kept in mind. 


\section{References}

Abidin, C. (2015). Communicative $<3$ intimacies: Influencers and perceived interconnectedness. Ada A Journal of Gender New Media \& Technology [Online]. 8, retrieved at http://adanewmedia.org/2015/11/issue8-abidin/.

Abidin, C. (2016). Visibility labor: Engaging with influencers' fashion brands and \#OOTD advertorial campaigns on Instagram. Media International Australia. 161(1), 86-100. https://doi.org/10.1177/1329878X16665177.

Balaban, D.C, Constantinescu, S \& Mustă?ea, M. (2018). Social media networks Unveiled. Mapping the Romanian and German Youth. Journal of Media Research. 11, 3(32), 35-44.

Benjamin K Johnson, Bridget Potocki, Jolanda Veldhuis, Is That My Friend or an Advert? The Effectiveness of Instagram Native Advertisements Posing as Social Posts, Journal of Computer-Mediated Communication, Volume 24, Issue 3, May 2019, Pages 108-125, https://doi.org/10.1093/jcmc/zmz003.

Carr, R., \& Heyes, C. (2015). Social Media: Defining, Developing, and Divining. Atlantic Journal of Communication. 23(1), 46-65.

Chadwick, A., Vaccari, C., \& O'Loughlin, B. (2018). Do Tabloids Poison the Well of Social Media? Explaining Democratically Dysfunctional News Sharing. New Media \& Society. 20(11), 1-20. https://doi.org/ $10.1177 / 1461444818769689$.

Chaffey, D. (2018). Global social media research summary 2018. Smart Insights [Online], retrieved at https:// www.smartinsights.com/social-media-marketing/social-media-strategy/new-global-social-media-research/.

Carpenter Childers, C., Lemon, L.L., \& Hoy, M.G. (2018). \#Sponsored \#Ad: Agency Perspective on Influencer Marketing Campaigns. Journal of Current Issues \& Research in Advertising. November, 1-18. https://doi.org/10.1080/10641734.2018.1521113.

Chen, L., \& Shupei, Y. (2018). Influencer Marketing: How Message Value and Journal of Interactive Advertising. https://doi.org/10.1080/15252019.2018.1533501.

Chen L. \& Yuan, S. (2018). Influencer Marketing: How Message Value and Credibility Affect Consumer Trust of Branded Content on Social Media. Journal of Interactive Advertising, https://doi.org/10.1080/1525 2019.2018.1533501.

Cialdini, R. B. (2001). Influence: Science and practice (4th ed.). Boston, MA: Allyn \& Bacon.

Colliander, J. \& Erlandsson, S. (2015). The blog and the beautiful: Exploring the effects of disguised products placement on blogs that are revealed to be third party. Journal of Marketing Communications, 21(2), 110-124.

Creswell, J. (2009). Research design-qualitative, quantitative and mixed method approaches. Thousand Oaks: Sage Publications.

De Veirman, M., Cauberghe, V., \& Hudders, L. (2017). Marketing through Instagram influencers: the impact of the number of followers and product divergence on brand attitude. International Journal of Advertising. 36(5), 798-828. https://doi.org/10.1080/02650487.2017.1348035.

de Vries, L., Gensler, S., \& Leeflang, P.S.H. (2012). Popularity of brand posts on brand fan pages: An investigation of the effects of social media marketing. Journal of Interactive Marketing. 26(2), 83-91. https:// doi.org/10.1016/j.intmar.2012.01.003.

Djafarova, E., \& Rushworth, C. (2017). Exploring the credibility of online celebrities' Instagram profiles in influencing the purchase decisions of young female users. Computers in Human Behavior. 68, 1-7.

Evans, N.J., Phua, J., Lim, J., \& Jun, H. (2017). Disclosing Instagram Influencer Advertising: The Effects of Disclosure Language on Advertising Recognition, Attitudes, and Behavioral Intent. Journal of Interactive Advertising. 17(2), 138-149. https://doi.org/10.1080/15252019.2017.1366885.

Erkan, I., \& Evans, C. (2016). The influence of eWOM in social media on consumers' purchase intentions: An extended approach to information adoption. Computers in Human Behavior. 61, 47-55.

Flanagin, A. J., \& Metzger, M. J. (2001). Internet use in the contemporary media environment. Human Communication Research. 27, 153-181.

Flanagin, A. J. (2017). Online social influence and the convergence of mass and interpersonal communication. Human Communication Research, 43, 450-463. doi:10.1111/hcre.12116.

Fogg, B. J., Marshall, J., Laraki, O., Osipovich, A., Varma, C., Fang, N., Paul, J., Rangnekar, A., Shon, J., Swani, P., \& Treinen, M. (2001b). What makes Websites credible? A report on a large quantitative study, CHI 2001. ACM Conference on Human Factors in Computing Systems, CHI Letter. 3(1), 61-68. 
Freberg, K., Graham, K., McGaughey, K., \& Freberg, L. A. (2011). Who are the social media influencers? A study of public perceptions of personality. Public Relations Review. 37(1), 90-92.

Gass, R. H., \& Seiter, J. S. (1999). Persuasion, social influence, and compliance gaining. Boston: Allyn \& Bacon. Goldsmith, R. E., Lafferty, B. A., \& Newell, S. J. (2000). The impact of corporate credibility and celebrity credibility on consumer reaction to advertisements and brands. Journal of Advertising. 29, 43-54.

Gottbrecht, L. (2016). The Three Types of Influencers All Marketers Should Know [Online], retrieved at http://www.mavrck.co/the-three-types-of-influencers-all-marketers-should-knowinfographic/.

Gottfried, J., \& Shearer, E. (2016). News use across social media platforms in 2016. Pew Research Center [Online], retrieved at http://www.journalism.org/2016/05/26/news-use-across-social-mediaplatforms-2016/.

Hall, J. (2015). Build authentic audience experiences through influencer marketing. Forbes [Online], retrieved at https://www.forbes.com/sites/johnhall/2015/12/17/build-authentic-audience-experiencesthrough-influencer-marketing/\#589d25fa4ff2.

Hall, K. (2016). The importance of authenticity in influencer marketing. Sprout Content [Online], retrieved at https://www.sproutcontent.com/blog/the-importance-of- authenticity-in-influencer-marketing.

Haley, E., Taylor, R., \& Morrison, M. (2014). How Advertising Creatives Define Excellent Planning. Journal of Current Issues \& Research in Advertising. 35(2), 167-189.

Ham, C.-D., Lee, J., Hayes, J. L., \& Bae, Y. H. (2018). Exploring sharing behaviors across social media platforms. International Journal of Market Research. 1-21. https://doi.org/10.1177/1470785318782790.

Horton, D., and R. Wohl. 1956. "Mass Communication and Parasocial Interaction: Observations on Intimacy at a Distance." Psychiatry 19: 219-229.

Hwang, Y. (2015). Does opinion leadership increase the followers on Twitter?. International Journal of Social Science and Humanity. 5(3), 258-264. https://doi.org/10.7763/IJSSH.2015.V5.464.

Johnson, T. J., \& Kaye, B. K. (1998). Cruising is believing?: Comparing Internet and traditional sources on media credibility measures. Journalism \& Mass Communication Quarterly. 75, 325-340.

Johnson, T. J., \& Kaye, B. K. (2000). Using is believing: The influence of reliance on the credibility of online political information among politically interested Internet users. Journalism \& Mass Communication Quarterly. 77, 865-879.

Katz, E., \& Lazarsfeld, P. (1955). Personal Influence: The Part Played by People in the Flow of Mass Communications. New York: The Free Press.

Keller, E., \& Fay, B. (2012). Word of Mouth Advocacy: A New Key to Advertising Effectiveness. Journal of Advertising Research. 52(4), 459-464.

Kelman, H. (1958). Compliance, identification, and internalization: ree processes of attitude change. Journal of Conflict Resolution, 1, 51-60. https://doi.org/10.1177/002200275800200106.

Kerstetter, D., \& Cho, M. (2004). Prior knowledge, credibility and information search. Annals of Tourism research. 31, 961-985. https://doi.org/10.1016/j.annals.2004.04.002.

Kim, S. T, Weaver, D., \& Willnat, L. (2001). Media reporting and perceived credibility of online polls. Journalism \& Mass Communication Quarterly. 77, 846-864.

Kiousis, S. (2001). Public trust or mistrust? Perceptions of media credibility in the Information Age. Mass Communication \& Society. 4, 381-403.

Kerstetter, D., \& Cho, M. (2004). Prior knowledge, credibility and information search. Annals of Tourism research. 31, 961-985. https://doi.org/10.1016/j.annals.2004.04.002.

Lazer, D., Baum, M., Benkler, J., Berinski, A., Greenhill, K., Menczer, F., Metzger, M., Nyhan, B., Pennycook, G., Rothchild, D., Schudson, M., Sloman, S., Sunstein, C., Thorson, E., Watts, D., \& Zittrain, J. (2018). The science of fake news. Science. 359, 1094-1096.

Lee, J., Kim, S., \& Ham, C.-D. (2016). A Double-Edged Sword? Predicting Consumers' Attitudes toward and Sharing Intention of Native Advertising on Social Media. American Behavioral Scientist. 60(12), 1425-1441.

Liu, F. (2007). Constrained Opinion Leader Influence in an Electoral Campaign Season: Revisiting the Two Step Flow Theory with Multi-Agent Simulation. Advances in Complex Systems. 10(2), 233-250.

Long, M. C. (2016). How Social Media is Changing Advertising - for Better and Worse. Adweek [Online], retrieved at http://www.adweek.com/digital/how-social-media-is-changing-advertising-for-better-and-worse/.

Mashek, J. W. (1997). Lethargy '96: How the media covered a listless campaign. Arlington. Virginia: The Freedom Forum. 
Matteo, S., \& Dal Zotto, C. (2015). Native Advertising, or How to Stretch Editorial to Sponsored Content within a Transmedia Branding Era. In Siegert, G., Forster, K., Chan-Olmsted, S.M., \& Ots, M. (Eds.). Handbook of Media Branding (pp.169-185). Cham: Springer International Publishing.

McGuire, W. (2001). Input and output variables currently promising for constructing persuasive communications. Public Communication Campaigns. 3, 22-48.

Metzger, M. J., Flanagin, A. J., Eyal, K., Lemus, D. R., \& McCann, R. M. (2003). Credibility for the 21st century: Integrating perspectives on source, message, and media credibility in the contemporary media environment. In Kalbfleisch, P. J. (Ed.). Communication yearbook 27 (pp. 293-335). Mahwah: Lawrence Erlbaum.

Metzger, M. J., Flanagin, A. J., \& Medders, R. (2010). Social and heuristic approaches to credibility evaluation online. Journal of Communication. 60(3), 413-439.

Munnukka, J., Uusitalo, O., \& Toivonen, H. (2016). Credibility of a peer endorser and advertising effectiveness. Journal of Consumer Marketing. 33(3), 182-192.

Nirschl, M., \& Steinberg, L. (2018). Einstieg in das Influencer Marketing. Grundlagen, Strategien und Erfolgsfaktoren. Wiesbaden: Springer Gabler.

Ohanian, R. (1990). Construction and validation of a scale to measure celebrity endorsers' perceived expertise, trustworthiness, and attractiveness. Journal of Advertising. 19(3), 39-52.

Perloff, R. M. (1993). The dynamics of persuasion. Hillsdale: Erlbaum.

Phua, J., Seung, A J., \& Kim, J. (2017). Gratifications of Using Facebook, Twitter, Instagram, or Snapchat to Follow Brands: The Moderating Effect of Social Comparison, Trust, Tie Strength, and Network Homophily on Brand Identification, Brand Engagement, Brand Commitment, and Membership Intention. Telematics and Informatics. 34(1), 412-424.

Rogers, E. M. (1964). Diffusion of innovations. New York: Free Press.

Stewart, K., \& Cunningham, I. (2017). Examining Consumers' Multiplatform Usage And Its Contribution to Their Trust in Advertising. The Impact of the Device on Platform-Use Frequency And Trust in Advertising across Platforms. Journal of Advertising Research. September, 250-259. https://doi.org/10.2501/ JAR-2017-003.

Sundar, S. S., \& Nass, C. (2001). Conceptualizing sources in online news. Journal of Communication, 51, 52-72.

Swart, J., Peters, C., \& Broersma, M. (2018). Shedding light on the dark social: The connective role of news and journalism in social media communities. New Media and Society. 1-17. https://doi.org/10.1177/1461 444818772063.

Teng, S., Khong, K. W., Goh, W., W., \& Chong, A.Y.L. (2014). Examining the antecedents of persuasive eWOM messages in social media. Online Information Review. 38(6), 746-768.

Tuchman, G. (2002). Media institutions. Qualitative methods in the study of news. In Jensen, K. B., \& Jankowski, N. W. (Eds.). A Handbook of Qualitative Methodologies for Mass Communication Research (pp. 79-92). London and New York: Routledge.

Van Dijck, J. (2013). The Culture of Connectivity. A Critical History of Social Media. Oxford, New York: Oxford University Press.

Van Dijck, J., Poell, T., \& DeWaal, M., (2018). The Platform Society. Public Values in Connective World. Oxford, New York: Oxford University Press.

Varsamis, E. (2018). Are social media influencers the next-generation brand ambassadors?. Forbes [Online], retrieved at https://www.forbes.com/sites/theyec/2018/06/13/are-social-media-influencers-the-next-gene ration-brand-ambassadors/\#2d8b9e82473d.

Wimmer, R. D., \& Dominick, J. R. (2011). Mass Media Research. An Introduction (9th ed.). Wadsworth Cengage Learning. Boston: Wadsworth.

Wilson, E. J., \& Sherrell, D. L. (1993). Source effects in communication and persuasion research: A metaanalysis of effect size. Journal of Academy of Marketing Science. 21, 101-112.

Wojdynski, B. W. (2016). Native advertising: Engagement, deception and implications for theory. In R. Brown, V. K. Jones, \& M. Wang (Eds.), The new advertising: Branding, content, and consumer relationships in a data-driven social media era (Vol. 1, pp. 203-236). Santa Barbara, CA: Praeger.

Xiao, M., Wang, R., \& Chan-Olmsted, S. (2018). Factors affecting YouTube influencer marketing credibility: a heuristic-systematic model. Journal of Media Business Studies. https://doi.org/10.1080/16522354. 2018.1501146. 
*** Bundeszenrale für Politische Bildung (2016), Nutzungsdauer tagesaktueller Medien in Deutschland seit 1990, Retrieved May 5, 2019 from https:/www.bpb.de/gesellschaft/medien-und-sport/medienpolit $\mathrm{ik} / 189224 /$ mediennutzung

*** Gemius (2018), Retrieved March 11, 2018 from https://www.gemius.com/agencies-news/romania-top5social-networks.html.

*** Interactive Advertising Bureau (IAB) (2018). Inside Influence, Retrieved February 2, 2018 from https:// www.iab.com/wpcontent/uploads/2018/01/IAB_Influencer_Marketing_for_Publishers_2018-01-25.pdf.

*** Media fact Book. (2018). Retrieved May 5, 2019 from http://www.mediafactbook.ro/preview.

*** Statista (2019a), Retrieved January, 30, 2019 from https://www.statista.com/chart/16259/instagram-us ers-europe/.

*** Statista (2019b), Retrieved January, 30, 2019 from https://www.statista.com/statistics/282846/regularsocial-networking-usage-penetration-worldwide-by-country/.

*** Statista (2019c), Retrieved January, 30, 2019, from https://www.statista.com/infografik/16256/facebookusers-in-europe/. 